\title{
Temperature affects the hypoxia tolerance of neotropical Cichlid Geophagus brasiliensis
}

\author{
Jéssica A. Pereira, Alexandra C.S. Veronez, Gabriel C. Coppo, Charles Duca, \\ Adriana R. Chippari-Gomes and Levy C. Gomes
}

\begin{abstract}
Oxygen and temperature are the most limiting factors in aquatic environments. Several species are exposed to variations of these factors in water because of physical, chemical and biological processes. The objective of this study was to evaluate the metabolic profile and the tolerance to the hypoxia of Geophagus brasiliensis exposed to changes in temperature and oxygen availability. The fish were exposed to 20 and $90 \%$ of oxygen saturation combined with different temperatures $\left(20^{\circ}, 24^{\circ}\right.$ and $\left.28^{\circ} \mathrm{C}\right)$ for $8 \mathrm{~h}$. Hepatic and muscular glycogen, as well as the activities of lactate dehydrogenase (LDH), malate dehydrogenase (MDH), citrate synthase (CS) and their ratios were evaluated. Both glycogen and MDH activity showed a significant difference in the liver. While CS showed increased activity only in the heart. The increase in LDH activity in the white muscle shows the importance of the anaerobic pathway as energy source in this tissue. The MDH / LDH ratio increased in all tissues, while CS / LDH increased in the liver and decreased in the heart. Based on the results of the present study it may be concluded that this species used the anaerobic metabolism as the main strategy for hypoxia tolerance.
\end{abstract}

Keywords: Aerobic and anaerobic pathways, Behavior, Metabolism, Oxygen.

O oxigênio e a temperatura são os fatores mais limitantes em ambientes aquáticos. Várias espécies são expostas a variações destes fatores na água como resultado de processos físicos, químicos e biológicos. O estudo objetivou avaliar o perfil metabólico e a tolerância à hipóxia de Geophagus brasiliensis expostos a alterações na temperatura e disponibilidade de oxigênio. Os peixes foram expostos a $20 \%$ e $90 \%$ de saturação de oxigênio combinadas com diferentes temperaturas (20 ${ }^{\circ} \mathrm{C}, 24^{\circ} \mathrm{C}$ e $28^{\circ} \mathrm{C}$ ) durante $8 \mathrm{~h}$. Foram avaliados o glicogénio hepático e muscular, assim como as atividades das enzimas lactato desidrogenase (LDH), malato desidrogenase (MDH), citrato sintase (CS) e suas razões. Tanto o glicogênio quanto a atividade da MDH apresentaram diferença significativa no fígado. Enquanto a CS apresentou aumento de sua atividade apenas no coração. O aumento da atividade LDH no músculo branco mostra a importância da via anaeróbia como fonte de energia neste tecido. A razão $\mathrm{MDH} / \mathrm{LDH}$ aumentou em todos os tecidos, enquanto CS/LDH apresentou aumento no fígado e diminuição no coração. Os resultados obtidos permitem concluir que esta espécie utilizou o metabolismo anaeróbio como principal estratégia de tolerância à hipóxia.

Palavras chave: Comportamento, Metabolismo, Oxigênio, Vias aeróbicas e anaeróbicas.

\section{Introduction}

Oxygen is one of the most limiting factors of the aquatic environment, and its depletion has been associated with the wide participation of human activities in environmental eutrophication (Diaz, Rosenberg, 2008). The availability of this gas in the water is essential for aquatic organisms, and it can influence their ecology, behavior and physiology (Martinez et al., 2011).

Biochemical and physiological changes such as changes in lactate dehydrogenase, anaerobic ATP production, increasing of gill ventilation, and reducing heartbeat frequency (McNeil, Closs, 2007) can occur after a situation of intense hypoxia. Metabolic suppression, carried out by reducing the demand for $\mathrm{O}_{2}$ and the use of anaerobic metabolism, is one of the most effective hypoxia tolerance strategies utilized by some species (Bickler, Buck, 2007).

The way how environmental physicochemical parameters, especially temperature, influence aquatic ecosystems is already known. They can directly influence the ecophysiological responses of organisms at different

Universidade Vila Velha - Av. Comissário José Dantas de Melo, 21, Boa Vista, Vila Velha 29102-920, ES, Brazil. (JAP) jpereirabio@hotmail.com, (ACSV) alexandra_veronez@hotmail.com, (GCC) gabriel.coppo@hotmail.com, (CD) cduca@uvv.br, (ARCG) adriana.chippari@uvv.br, (LCG) levy.gomes@uvv.br, @ittps://orcid.org/0000-0001-5826-2431 (corresponding author). 
levels at the ecosystem (Pörtner, Peck, 2010), especially ectothermic organisms, which are characterized by dependence on the heat of their environment to regulate their body temperature. Especially the temperature can act like a "ecological driving force" in the aquatic environment, influencing all biological parameters (Guderley, 2004), for example, a change of the temperature may affect the fish tolerance to hypoxia and the energy consumption (Yang et al., 2015). The tolerance limits and the ability of species to adapt to new temperature regimes are determining factors for the success of a population that is subjected to changes in this variable (Pörtner, Knust, 2007).

An increase in hypoxic zones by stratification of water bodies, together with the increased oxygen demand from organisms due to an increase in metabolic rate, are some of the consequences of temperature change (Stramma et al., 2008). Oxygen and temperature can also interact to form the "thermal oxygen pressure", wherein the organism, through a "trade-off", faces a confrontation between changing their physiology depending on either temperature or the oxygen level (Taylor et al., 2007). Recently, the hypoxic conditions have been aggravated because of intensification of global warming (Roze et al., 2013), making the effect of temperature on hypoxia tolerance in fish an important subject to investigate (He et al., 2015) as hypoxia tolerance can differ between different species (Borowiec et al., 2016).

Geophagus brasiliensis (Quoy \& Gaimard, 1824) has great variety in its morphology, and its occurrence covers a wide geographical area in South American, including tropical and subtropical regions. Therefore, the populations of this fish are exposed to different environmental conditions including variations in water temperature and oxygen concentration. Perazzo et al. (2013) suggested that speciation events for this species were due to this environmental variability. Because environmental adaptation plays an important role in determining species distributions among heterogeneous environments, and is important to know the adaptive characteristics of $G$. brasiliensis considering that this species is widely distributed in different environmental conditions. Thus, this study aimed to measure the tolerance of $G$. brasiliensis to hypoxia at different temperatures through its physiological and metabolic responses.

\section{Material and Methods}

Experimental fish. Geophagus brasiliensis (8.31 \pm $0.87 \mathrm{~g}$ ) were purchased from a private fish farm located in Guarapari, Espirito Santo State, Brazil and taken to the laboratory, where they were kept in standard acclimatization conditions for 30 days $(1,000 \mathrm{~L}$ tank, natural photoperiod, fed twice a day, $70 \%$ of the water exchanged once a week, physicochemical parameters monitored daily) at $28^{\circ} \mathrm{C}$. After this period, the fish were individually transferred to $30 \mathrm{~L}$ aquaria and were acclimatized for 14 days at the following experimental temperatures: $20^{\circ} \mathrm{C}\left(20 \pm 0.09^{\circ} \mathrm{C}\right), 24^{\circ} \mathrm{C}\left(24.12 \pm 0.21^{\circ} \mathrm{C}\right)$ and $28^{\circ} \mathrm{C}\left(28.04 \pm 0.11^{\circ} \mathrm{C}\right)$ under normoxia conditions $(90 \% \pm 4.05 \%$ oxygen saturation). The decrease of the temperature was performed progressively $\left(2^{\circ} \mathrm{C}\right.$ per day $)$ from $28^{\circ} \mathrm{C}$ to 24 or $20^{\circ} \mathrm{C}$. This process was controlled using a $110 \mathrm{~W}$ resistor places in the aquaria coupled to a digital thermostat accurate to one decimal place. These temperatures represent the temperature range in which the species is found in the wild (Rantin, Petersen, 1985).

The fish were fed twice a day with commercial fish feed with $45 \%$ crude protein. The aquariums were cleaned daily, and $70 \%$ of the water was exchanged weekly. Total ammonia $(1.34 \pm 0.21 \mathrm{mg} / \mathrm{L})$, nitrite $(0.06 \pm 0.03 \mathrm{mg} / \mathrm{L})$

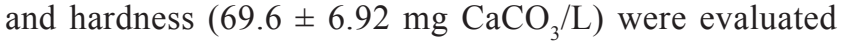
according to APHA (1998) twice a week, before and after the water exchange.

After identification, the voucher specimen was deposited in the ichthyological collection of the Museu de Biologia Professor Mello Leitão, Santa Teresa - ES (MBML - PEIXES 12643). The experiment was authorized by the animal experimentation committee of the institution (CEUA - UVV), in accordance to research protocol $\mathrm{n}^{\circ}$. $305 / 2014$.

Experimental design. Fish from each temperature group were individually transferred to an experimental aquarium containing $10 \mathrm{~L}$ of water and constant aeration at the same temperature as their acclimatization. The fish remained there for 24 hours before starting the experiment. A 150 $\mathrm{W}$ thermostat was used to reach and maintain the desired experimental temperature. An oxygen reading chamber was used to monitor the oxygen that was given in $\mathrm{mg} / \mathrm{L}$. The chamber was connected on one side to a submerged pump inside the aquarium; on another side, the probe of a Multiparameter device was inserted that performed the readings of percentage of oxygen saturation and temperature throughout the experiment, thus forming a closed water circulation system.

Different oxygen conditions, normoxia $(90 \% \pm 3.41 \%$ oxygen saturation) and hypoxia $(20 \% \pm 2.68 \%$ oxygen saturation), were combined with different temperatures, $20^{\circ} \mathrm{C}\left(20.7 \pm 0.37^{\circ} \mathrm{C}\right), 24^{\circ} \mathrm{C}\left(23.7 \pm 0.84^{\circ} \mathrm{C}\right)$ and $28^{\circ} \mathrm{C}$ $\left(28.5 \pm 0.7^{\circ} \mathrm{C}\right)$, totaling six treatments with eight replicates for each (total $n=48$ ). Each experiment lasted 8 hours (Chippari-Gomes et al., 2005). For treatments with hypoxic conditions, the aeration was removed at the beginning of the experiment, and the aquarium was completely closed, thus preventing any gaseous exchange with the environment. The oxygen was gradually reduced (from $25 \%$ saturation per hour) using the introduction of nitrogen gas bubbles in the water according to ChippariGomes et al. (2005). Once the desired $20 \%$ of oxygen saturation was achieved, the nitrogen introduction stopped and the eight experimental hours started (Chippari-Gomes et al., 2005). 
At the end of the experiment, the animals were anesthetized with eugenol $(100 \mathrm{mg} / \mathrm{L})$ and the blood sample was collected using a syringe contained EDTA for the plasma lactate determination. For these analyses, we used a Kit by Katal (K11B). The fish were euthanized by spinal cord section and the liver, heart and white muscle tissues were excised. Part of the liver and muscle were weighed and stored in test tubes containing $1 \mathrm{~mL}$ of $\mathrm{KOH}$ (potassium hydroxide) for glycogen analysis. The rest of these tissues and the heart were immediately stored in a $-80^{\circ} \mathrm{C}$ freezer for further analysis.

The determination of concentration of hepatic and white muscle glycogen was performed according to Dubois et al. (1956) with modifications. The reading was made in a spectrophotometer at $480 \mathrm{~nm}$ and the concentration was expressed in $\mu \mathrm{mol} \mathrm{g} \mathrm{g}^{-1}$.

Heart, white muscle and liver tissues were homogenized with EDTA buffer (ethylene diamino tetraacetic acid) $1 \mathrm{mM}$ containing $1 \%$ Triton $\mathrm{X}-100$ (octylphenoxypolyethoxyethanol) and $20 \mathrm{mM}$ Hepes (hydroxyethylpiperazine etanosulfuric acid) and had the $\mathrm{pH}$ adjusted to 7.4 for citrate synthase enzyme (CS). For lactate dehydrogenase (LDH) and malate dehydrogenase enzymes (MDH), $150 \mathrm{mM}$ imidazole buffer containing $1 \mathrm{mM}$ EDTA and $1 \%$ Triton X-100 (pH 7.4) was used. The homogenate was used at a 1:3 dilution for liver and muscle and 1:9 dilution for heart. They were centrifuged at $13,000 \mathrm{~g}$ for 15 minutes in a centrifuge Eppendorf $5417 \mathrm{R}$ at $4^{\circ} \mathrm{C}$. The enzyme assays were performed with the extract (supernatant portion) at $25^{\circ} \mathrm{C}$. Enzyme levels were measured by oxidation of NADH at $340 \mathrm{~nm}$ (molar extinction coefficient $\mathrm{mM}=6.22$ ) for $\mathrm{LDH}$ and $\mathrm{MDH}$ enzymes and via the oxidation of DTNB at $412 \mathrm{~nm}$ (molar extinction coefficient $\mathrm{mM}=13.6$ ) for $\mathrm{CS}$ enzyme.

Enzyme activity levels were determined according to techniques reviewed by Driedzic, Almeida-Val (1996) with modifications. The activity of LDH and $\mathrm{MDH}$ enzymes was obtained in $0.15 \mathrm{mM}$ NADH, $1 \mathrm{mM} \mathrm{KCN}$ in $50 \mathrm{mM}$ imidazole, $\mathrm{pH}$ 7.4. The LDH enzyme reactions were initiated with the addition of $1 \mathrm{mM}$ pyruvic acid, and MDH enzyme was initiated with the addition of $0.5 \mathrm{mM}$ oxalacetic acid. The CS enzyme activity was obtained in $0.25 \mathrm{mM}$ DTNB, $75 \mathrm{mM}$ Tris, and $\mathrm{pH}$ 8.0. The reactions were initiated with the addition of $0.04 \mathrm{mM}$ acetyl CoA and $0.5 \mathrm{mM}$ oxalacetic acid. The amount of protein was quantified by Bradford method (Bradford, 1976).

Statistical analysis. All data were evaluated for normality of the residuals using the Shapiro-Wilk test and the data that did not have normal distribution were normalized by transformation to $\log 10$ or $1+\log 10$. For enzyme activity and glycogen level analysis as function of temperature and oxygen conditions as independent variables, two-way ANOVA was used $(p<0.05)$. Analyses were performed using the program SigmaStat version 12.5 (Systat Software, Inc.).

\section{Results}

The muscle glycogen concentration did not differ between treatments. However, in liver, the glycogen concentration showed significant reductions at $24^{\circ} \mathrm{C}$ and $28^{\circ} \mathrm{C}$ in hypoxia (Tab. 1). The lactate concentration in blood plasma did not differ between treatments (Tab. 1).

In white muscle and heart tissues, the activity of the enzyme MDH did not differ among the different conditions of oxygen and temperatures (Figs. 1b,c, respectively; Tab. 2). However, its activity in the liver showed a significant reduction in hypoxia but without a difference between the temperatures (Fig. 1a; Tab. 2).

LDH enzyme activity did not differ between the different conditions of oxygen and temperatures in the liver and heart tissues (Figs. 2a,c, respectively; Tab. 2). In muscle, however, there was a significant difference in the activity of this enzyme at $28^{\circ} \mathrm{C}$, where the normoxic condition showed greater activity than hypoxia (Fig. 2b; Tab. 2).

The CS enzyme activity did not show difference between treatments in liver and muscle tissues (Figs. 3a,b, respectively; Tab. 2). In the heart, there was a significant increase in the activity at $24^{\circ} \mathrm{C}$ and $28^{\circ} \mathrm{C}$ in normoxia (Fig. 3c; Tab. 2).

The ratio between the activities of the enzymes MDH/ $\mathrm{LDH}$ and $\mathrm{CS} / \mathrm{LDH}$ was performed. As the ratio of enzymes $\mathrm{MDH} / \mathrm{LDH}$, the muscle showed an increase in hypoxia at $28^{\circ} \mathrm{C}$. In liver and heart, this increase appeared at the temperatures $24^{\circ} \mathrm{C}$ and $28^{\circ} \mathrm{C}$ in hypoxia. Referring to ratio between the enzymes CS/LDH, no difference was observed in muscle. However, in the liver an increase was shown at $24^{\circ} \mathrm{C}$ and $28^{\circ} \mathrm{C}$ in hypoxia, unlike the heart that showed a reduction at these temperatures and an increase at $20^{\circ} \mathrm{C}$ in the same oxygen concentration (Tab. 3).

Tab. 1. Two-way ANOVA of liver glycogen and blood lactate in Geophagus brasiliensis exposed to $20^{\circ} \mathrm{C}, 24^{\circ} \mathrm{C}$ and $28^{\circ} \mathrm{C}$ in normoxia ( $90 \%$ oxygen saturation) and hypoxia ( $20 \%$ oxygen saturation) conditions for 8 hours.

\begin{tabular}{|c|c|c|c|c|}
\hline \multirow{2}{*}{ Condition } & \multicolumn{4}{|c|}{ Temperature $\left({ }^{\circ} \mathrm{C}\right)$} \\
\hline & \multicolumn{2}{|c|}{$20^{\circ} \mathrm{C}$} & $24^{\circ} \mathrm{C}$ & $28^{\circ} \mathrm{C}$ \\
\hline \multicolumn{5}{|c|}{ Liver Glycogen } \\
\hline Normoxia & \multicolumn{2}{|c|}{$587.1 \pm 101.9^{a}$} & $846.6 \pm 192.0^{\mathrm{b}}$ & $853.7 \pm 88.6^{\mathrm{b}}$ \\
\hline Hypoxia & \multicolumn{2}{|c|}{$715.8 \pm 173.2^{\mathrm{a}}$} & $559.7 \pm 220.1^{* a}$ & $427.7 \pm 177.7^{* b}$ \\
\hline \multicolumn{5}{|c|}{ Plasma Lactate } \\
\hline Normoxia & \multicolumn{2}{|c|}{$0.98 \pm 0.76$} & $0.62 \pm 0.61$ & $0.54 \pm 0.18$ \\
\hline Hypoxia & \multicolumn{2}{|c|}{$0.86 \pm 0.89$} & $0.77 \pm 0.65$ & $0.73 \pm 0.36$ \\
\hline \multicolumn{5}{|c|}{ Two-Way ANOVA Glycogen } \\
\hline \multicolumn{2}{|c|}{ Source of Variation } & df & $\mathrm{F}$ & $p$ \\
\hline \multicolumn{2}{|c|}{ Temperature } & 2 & 0.652 & 0.526 \\
\hline \multicolumn{2}{|c|}{ Condition } & 1 & 16.558 & $<0.001$ \\
\hline \multicolumn{2}{|c|}{ Temperature X Condition } & 2 & 12.123 & $<0.001$ \\
\hline \multicolumn{5}{|c|}{ Two-Way ANOVA Lactate } \\
\hline \multicolumn{2}{|c|}{ Source of Variation } & $\mathrm{df}$ & $\mathrm{F}$ & $p$ \\
\hline \multicolumn{2}{|c|}{ Temperature } & 2 & 0.924 & 0.405 \\
\hline \multicolumn{2}{|c|}{ Condition } & 1 & 0.314 & 0.578 \\
\hline \multicolumn{2}{|c|}{ Temperature X Condition } & 2 & 0.612 & 0.547 \\
\hline
\end{tabular}




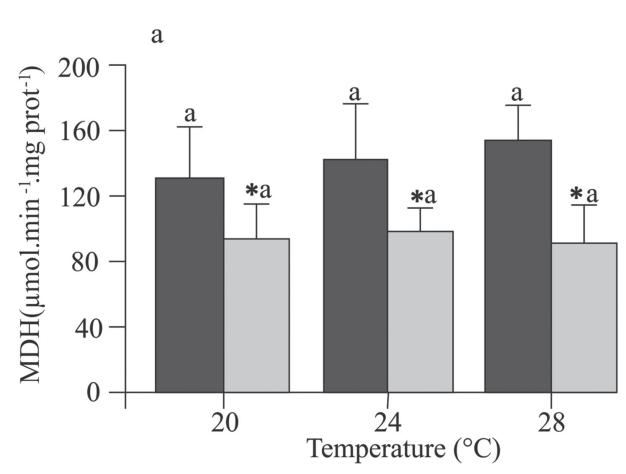

Normoxia Hypoxia
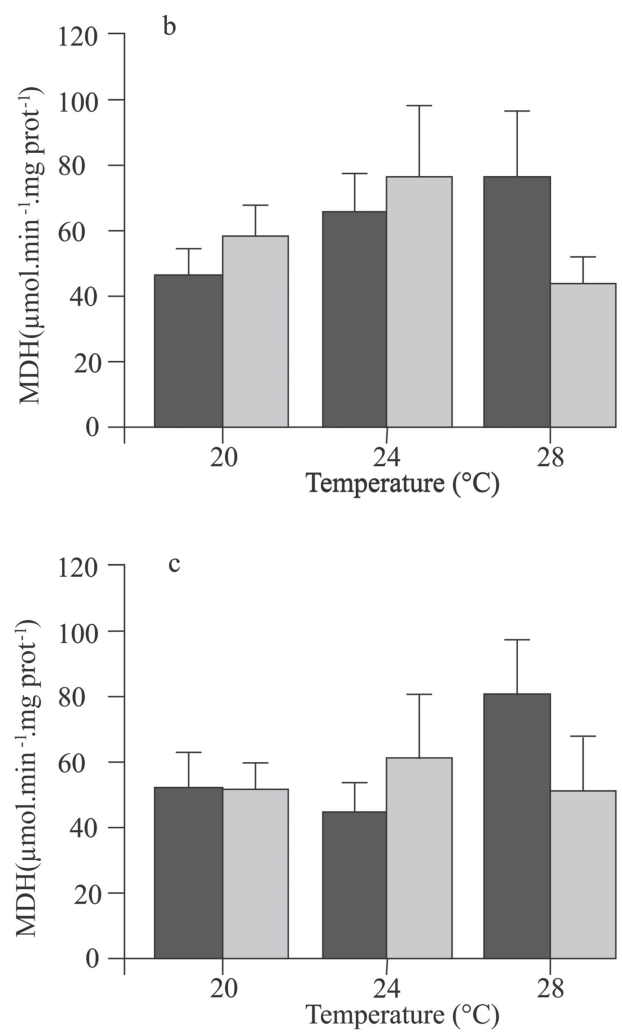

Fig. 1. Malate Dehydrogenase enzyme activity of Geophagus brasiliensis exposed to normoxic ( $90 \%$ oxygen saturation) and hypoxia (20\% oxygen saturation) conditions for 8 hours at $20^{\circ} \mathrm{C}, 24^{\circ} \mathrm{C}$ and $28^{\circ} \mathrm{C}$. a. in liver; b. in white muscle; and c. in heart. Asterisks indicates significant differences between treatments at the same temperature, $p<0.05$. Different lowercase letters indicate significant differences for the same treatment at the temperatures studied, $\mathrm{p}<0.05$.

\section{Discussion}

Factors such as temperature and oxygen availability may not be stressful when isolated, but the interaction between these parameters can cause a stressful situation and cause serious impacts on fish (McBryan et al., 2013). In normal oxygen conditions where energy demand is low, carbohydrate is stored mainly in the form of glycogen in the liver. In hypoxic conditions and the consequently
Tab. 2. Two-way ANOVA of Malate Dehydrogenase (MDH), Lactate Dehydrogenase (LDH) and Cytrate Synthase (CS) activity in Geophagus brasiliensis exposed to $20^{\circ} \mathrm{C}, 24^{\circ} \mathrm{C}$ and $28^{\circ} \mathrm{C}$ in normoxia $(90 \%$ oxygen saturation) and hypoxia ( $20 \%$ oxygen saturation) conditions for 8 hours.

\begin{tabular}{|c|c|c|c|}
\hline Source of Variation & df & $\mathrm{F}$ & $p$ \\
\hline \multicolumn{4}{|c|}{ Malate Dhydrogenase (MDH) } \\
\hline \multicolumn{4}{|c|}{ Liver } \\
\hline Temperature & 2 & 0.075 & 0.928 \\
\hline Condition & 1 & 5.687 & 0.022 \\
\hline Temperature $X$ Condition & 2 & 0.264 & 0.769 \\
\hline \multicolumn{4}{|c|}{ Muscle } \\
\hline Temperature & 2 & 0.810 & 0.451 \\
\hline Condition & 1 & 0.198 & 0.659 \\
\hline Temperature X Condition & 2 & 2.065 & 0.140 \\
\hline \multicolumn{4}{|c|}{ Heart } \\
\hline Temperature & 2 & 0.462 & 0.633 \\
\hline Condition & 1 & 0.455 & 0.504 \\
\hline Temperature X Condition & 2 & 1.009 & 0.374 \\
\hline \multicolumn{4}{|c|}{ Lactate Dehydrogense (LDH) } \\
\hline \multicolumn{4}{|c|}{ Liver } \\
\hline Temperature & 2 & 0.296 & 0.746 \\
\hline Condition & 1 & 1.437 & 0.239 \\
\hline Temperature X Condition & 2 & 1.154 & 0.327 \\
\hline \multicolumn{4}{|c|}{ Muscle } \\
\hline Temperature & 2 & 3.170 & 0.055 \\
\hline Condition & 1 & 4.509 & 0.041 \\
\hline Temperature X Condition & 2 & 3.544 & 0.040 \\
\hline \multicolumn{4}{|c|}{ Heart } \\
\hline Temperature & 2 & 0.974 & 0,388 \\
\hline Condition & 1 & 1.890 & 0.179 \\
\hline Temperature X Condition & 2 & 1.601 & 0.217 \\
\hline \multicolumn{4}{|c|}{ Citrate Synthase (CS) } \\
\hline \multicolumn{4}{|c|}{ Liver } \\
\hline Temperature & 2 & 0.420 & 0.660 \\
\hline Condition & 1 & 1.055 & 0.310 \\
\hline Temperature X Condition & 2 & 0.018 & 0.982 \\
\hline \multicolumn{4}{|c|}{ Muscle } \\
\hline Temperature & 2 & 0.0888 & 0.915 \\
\hline Condition & 1 & 0.0050 & 0.944 \\
\hline Temperature X Condition & 2 & 0.949 & 0.395 \\
\hline \multicolumn{4}{|c|}{ Heart } \\
\hline Temperature & 2 & 2.583 & 0.089 \\
\hline Condition & 1 & 24.646 & $<0.001$ \\
\hline Temperature X Condition & 2 & 5.343 & 0.009 \\
\hline
\end{tabular}

greater energy requirements, glycogen is rapidly used for the maintenance of basal functions and to supply anaerobic metabolism, thus reducing its concentration in tissues (Chippari-Gomes et al., 2005). At lower temperatures fish may improve their hypoxia tolerance because of the reduced energy consumption and high concentration of glycogen (Yang et al., 2015). The significant reduction of glycogen in the liver under hypoxic conditions at highest temperatures $\left(24^{\circ} \mathrm{C}\right.$ and $\left.28^{\circ} \mathrm{C}\right)$ corroborates this hypothesis. 

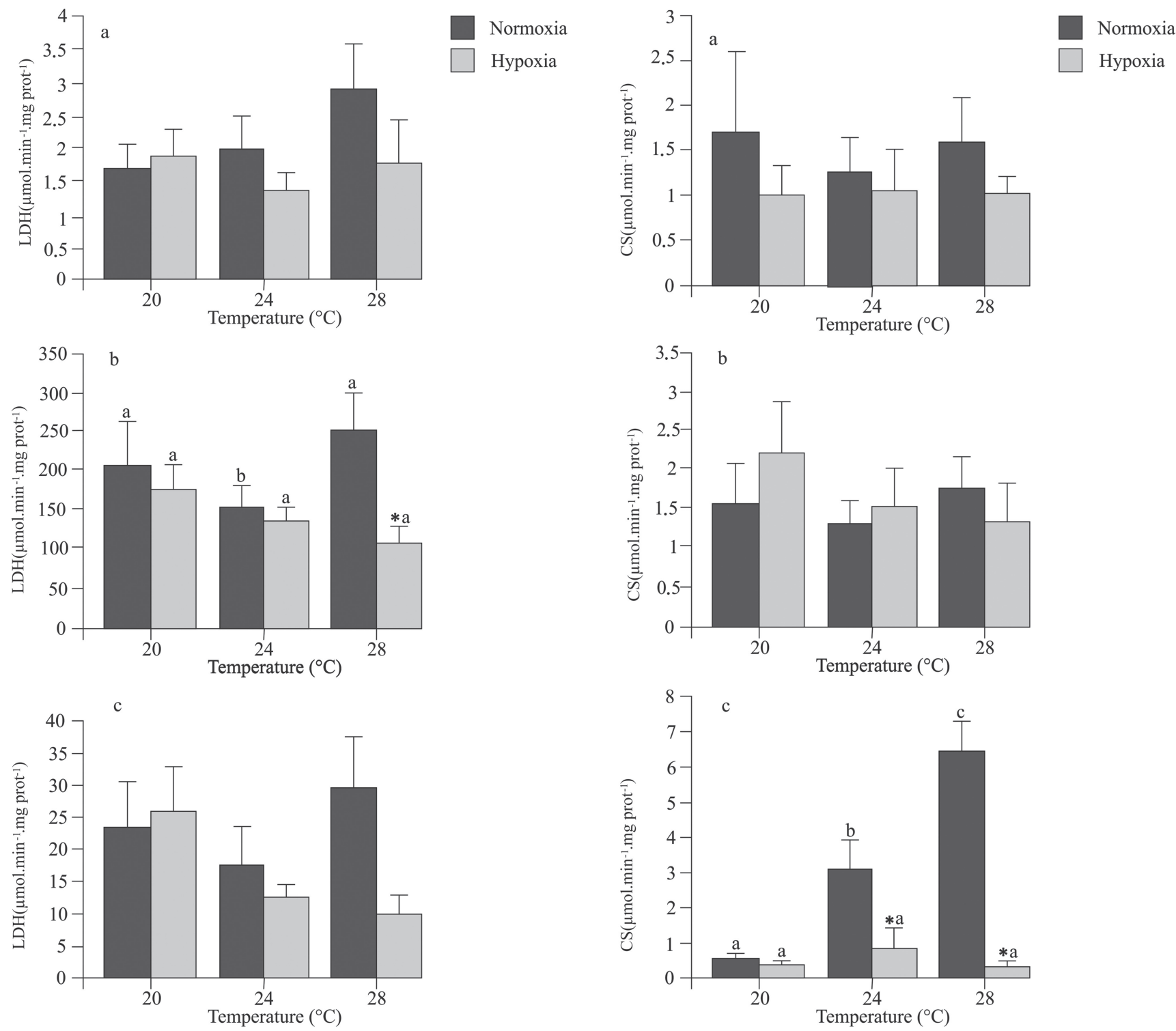

Fig. 2. Lactate Dehydrogenase enzyme activity of Geophagus brasiliensis exposed to normoxic (90\% oxygen saturation) and hypoxic ( $20 \%$ oxygen saturation) conditions for 8 hours at $20^{\circ} \mathrm{C}, 24^{\circ} \mathrm{C}$ and $28^{\circ} \mathrm{C}$. a. in liver; $\mathbf{b}$. in white muscle; and c. in heart. Asterisks indicates significant differences between treatments at the same temperature, $\mathrm{p}<0.05$. Different lowercase letters indicate significant differences for the same treatment at the temperatures studied, $\mathrm{p}<0.05$.

Fig. 3. Citrate Synthase enzyme activity of Geophagus brasiliensis exposed to normoxic (90\% oxygen saturation) and hypoxic ( $20 \%$ oxygen saturation) conditions for 8 hours at $20^{\circ} \mathrm{C}, 24^{\circ} \mathrm{C}$ and $28^{\circ} \mathrm{C}$. a. in liver; $\mathbf{b}$. in white muscle; and c. in heart. Asterisks indicates significant differences between treatments at the same temperature, $\mathrm{p}<0.05$. Different lowercase letters indicate significant differences for the same treatment at the temperatures studied, $\mathrm{p}<0.05$.

Tab. 3. Enzimatic ratios in liver, muscle and heart in Geophagus brasiliensis exposed to $20^{\circ} \mathrm{C}, 24^{\circ} \mathrm{C}$ and $28^{\circ} \mathrm{C}$ in normoxia $(90 \%$ oxygen saturation) and hypoxia $(20 \%$ oxygen saturation $)$ conditions for 8 hours. Temp. $=$ Temperature; Cond. $=$ Condition .

\begin{tabular}{|c|c|c|c|c|c|c|c|}
\hline \multirow{2}{*}{ Temp. $\left({ }^{\circ} \mathrm{C}\right)$} & \multirow{2}{*}{ Cond. } & \multicolumn{2}{|c|}{ Liver } & \multicolumn{2}{|c|}{ Muscle } & \multicolumn{2}{|c|}{ Heart } \\
\hline & & $\mathrm{MDH} / \mathrm{LDH}$ & $\mathrm{CS} / \mathrm{LDH}$ & $\mathrm{MDH} / \mathrm{LDH}$ & $\mathrm{CS} / \mathrm{LDH}$ & $\mathrm{MDH} / \mathrm{LDH}$ & $\mathrm{CS} / \mathrm{LDH}$ \\
\hline \multirow{2}{*}{20} & Normoxia & 59.71 & 0.93 & 0.24 & 0.01 & 2.60 & 0.02 \\
\hline & Hypoxia & 48.21 & 0.50 & 0.29 & 0.01 & 1.95 & 0.14 \\
\hline \multirow{2}{*}{24} & Normoxia & 67.42 & 0.61 & 0.62 & 0.01 & 3.83 & 0.25 \\
\hline & Hypoxia & 104.44 & 1.12 & 0.41 & 0.01 & 5.76 & 0.07 \\
\hline \multirow{2}{*}{28} & Normoxia & 61.11 & 0.63 & 0.23 & 0.01 & 2.81 & 0.22 \\
\hline & Hypoxia & 83.69 & 1.32 & 0.41 & 0.01 & 8.19 & 0.05 \\
\hline
\end{tabular}


The lactate accumulation is usually response to hypoxia and indicate the use of anaerobic metabolism, since this is the final product of this metabolic pathway. However, some fish species like $G$. brasiliensis when in oxygen deprivation periods choose not to use this pathway, which seems to be an important metabolic adjustment to prevent the acidosis caused by the lactate accumulation (Omlin, Weber, 2010), and the ability to reduce acidosis by the reduction of energy demand by metabolic suppression has been showed by tolerant species (Jackson, 2004).

The significant reduction of MDH enzyme activity in the liver when in hypoxic condition indicates the ability of metabolic suppression of this species is a way of saving energy, and so it consigns it to higher energy requirement organs such as the heart. Kumar, Gopesh (2015) found a similar result, they also observed the reduction of $\mathrm{MDH}$ activity in the liver of Clarias batrachus in hypoxia condition. Additionally, because this is an enzyme that participates in the production of glucose (gluconeogenesis) and the liver is an important organ in this process, the reduction of $\mathrm{MDH}$ activity in this tissue may indicate a reduction in glycogen storage, which corroborates with the reduction in its reserve under the influence of hypoxia observed in this study.

$\mathrm{LDH}$ is a major enzyme in the activation of anaerobic metabolism. Environmental anaerobiosis, stimulated by changes in environmental conditions such as oxygen, occurs gradually and does not require a rapid activation of anaerobic metabolism. Organisms that are more tolerant to low oxygen concentration save energy by reducing the demand for ATP combined with the deletion of certain physiological functions. Thus, these organisms tend to have a preference to tolerate situations of low oxygen supply, hoping this will be available again, and to develop anaerobic pathways that yield more ATP in relation to the fermentation of lactate. These pathways final release products such as ethanol and acetate, unlike lactate, can be excreted easily preventing tissue acidosis (Hochachka et al., 1993).

As the major determinants of survival of fish in hypoxia are metabolic suppression, a large stock of glycogen in tissues and the ability to avoid acidosis (Lutz, Nilsson, 1997), the absence of increased LDH activity in the liver in hypoxic condition together with the glycogen storage mobilization in this condition indicates the ability of G. brasiliensis to prevent acidosis caused by lactate accumulation in the liver.

In muscle, however, LDH showed a significant increase in its activity in normoxia at $28^{\circ} \mathrm{C}$, like Campos et al. (2017) observed for Paracheirodon axelrodi and Paracheirodon simulans at high temperatures, under normal oxygen conditions, demonstrating that the muscle works anaerobically. At higher temperatures, the production of ATP by aerobic pathways is reduced, although under normal oxygen conditions, which reflect a higher energy cost for the maintenance of homeostasis, the use of anaerobic metabolism is required (Pörtner, 2004). Thus, the major energy source in the white muscle of G. brasiliensis, observed by the expected increase in LDH activity because this is essentially anaerobic tissue, indicates an adaptive ability of the species to survive at higher temperatures and the important role of LDH enzyme in energy support of this tissue during periods when more energy is required (Hochachka, Somero, 2002). The activity of this enzyme showed a reduction in the same temperature under hypoxic condition in this study. The ability of muscle to maintain its function in hypoxic conditions by using the anaerobic metabolism, although this glycolytic pathway is reduced, has been observed in previous studies (Almeida-Val et al., 1999).

When exposing individuals of Clarias batachus to hypoxia conditions Kumar, Gopesh (2015) observed that after 24 hours LDH activity increased in the heart and after 48 hours decreased to almost normal condition. Differing from the results obtained in the present study, where we did not find significant differences in the LDH activity in the heart, under normoxia or hypoxia.

The increase in the activity of the CS enzyme in the heart at $24^{\circ} \mathrm{C}$ and $28^{\circ} \mathrm{C}$ in normoxia indicates the extreme dependence on aerobic metabolism of this tissue. However, the significant reduction of its activity under the influence of hypoxia suggests the realization of metabolic suppression as a more advantageous option in relation to the activation of anaerobic metabolism during periods of low oxygen availability.

The increase in the ratio between the enzymes CS/LDH and especially $\mathrm{MDH} / \mathrm{LDH}$ in the liver in hypoxic conditions at $24^{\circ} \mathrm{C}$ and $28^{\circ} \mathrm{C}$, shows that this tissue potentiates the aerobic metabolism during low oxygen concentrations, indicating that this should be a strategy to avoid the accumulation of end products of anaerobic metabolism, such as lactic acid. Saavedra et al. (2016) also found high values for the $\mathrm{MDH} / \mathrm{LDH}$ ratio, studying heart and liver from species of deep sea (Beryx splendens and Hoplosthetus atlanticus), where there are minimal oxygen conditions. The same pattern was observed in the heart of G. brasiliensis that showed an inhibition of anaerobic metabolism under hypoxia conditions in $24^{\circ} \mathrm{C}$ and $28^{\circ} \mathrm{C}$, which also showed us that, this is an aerobic tissue, confirming the increase of CS activity at these same temperatures in normoxia.

It is important that more studies be done regarding metabolic changes resulting from global scale environmental changes, especially on temperature dependence in anaerobic metabolism (Sørensen et al., 2014), so we can understand better how organisms adapt and what strategies they use in the face of new environmental conditions, since it is estimated that the temperature will increase from 1 to $7^{\circ} \mathrm{C}$ in the next 100 years (IPCC, 2014).

A change in the availability of dissolved oxygen in the water can generate serious impacts on the survival of some species and consequently on the diversity of species in a region, in the trophic relationships and in other ecological parameters (Ekau et al., 2010). The impact of hypoxic conditions on the environment may reduce local biodiversity, as well as environmental resilience and resistance (Ekau et al., 2010), and may influence the 
nutrient cycling processes (Jennings, Wilson, 2009). The availability of oxygen also influences fish physiological parameters, such as growth, reproduction and food intake. The reduction in food intake is an important factor, since it consequently reduces the energy demand and the oxygen demand (Ekau et al., 2010).

Geophagus brasiliensis use the anaerobic metabolism as the main strategy for optimizing its strength in the absence of oxygen, because of mobilization of its energy reserves (i.e. LDH activity in white muscle). The synergistic effect of high temperature and low oxygen availability influences the mechanisms of the G. brasiliensis.

\section{Acknowledgments}

This work was supported by Fundação de Amparo à Pesquisa e Inovação do Espírito Santo (FAPES). Levy Gomes is the recipient of a research fellowship from Conselho Nacional de Desenvolvimento Científico e Tecnológico $(\mathrm{CNPq})$. The authors thank the Instituto Nacional da Mata Atlântica (INMA) for accepting the deposit of voucher specimen in Museu de Biologia Professor Mello Leitão.

\section{References}

Almeida-Val VMF, Paula-Silva MN, Duncan WP, Lopes NP, Val $\mathrm{AL}$, Land SC. Increase of anaerobic potential during growth of an Amazonian cichlid, Astronotus ocellatus. Survivorship and LDH regulation after hypoxia exposure. In: Val AL, AlmeidaVal VMF, editors. Biology of tropical fishes. Manaus: INPA; 1999. p.437-448.

APHA. Standard methods for the examination of water and wastewater. 20th ed. Washington: American Public Health Association, American Water Works Association, Water Environmental Federation; 1998.

Bickler PE, Buck LT. Hypoxia tolerance in reptiles, amphibians, and fishes: life with variable oxygen availability. Annu Rev Physiol. 2007; 69:145-70.

Borowiec BG, Crans KD, Khajali F, Pranckevicius NA, Young A, Scott GR. Interspecific and environment-induced variation in hypoxia tolerance in sunfish. Comp Biochem Physiol A. 2016; 198:59-71

Bradford MM. A rapid and sensitive method for the quantification of microgram quantities of protein utilizing the protein-dye binding. Anal Biochem. 1976; 72(1-2):248-54.

Campos DF, Jesus TF, Kochhann D, Heinrichs-Caldas W, Coelho MM, Almeida-Val VMF. Metabolic rate and thermal tolerance in two congeneric Amazon fishes: Paracheirodon axelrodi Schultz, 1956 and Paracheirodon simulans Géry, 1963 (Characidae). Hydrobiologia. 2017; 789(1):133-42.

Chippari-Gomes AR, Gomes LC, Lopes NP, Val AL, AlmeidaVal VMF. Metabolic adjustments in two Amazonian cichlids exposed to hypoxia and anoxia. Comp Biochem Physiol B. 2005; 141(3):347-55.

Diaz RJ, Rosenberg R. Spreading dead zone and consequences for marine ecosystems. Science. 2008; 321(5891):926-29.
Driedzic WR, Almeida-Val VMF. Enzymes of cardiac energy metabolism in Amazonian teleosts and fresh-water stingray (Potamotrygon hystrix). J Exp Zool. 1996; 274(6):327-33.

Dubois MG, Gilles KA, Hamilton JK, Rebers PA, Smith F. Colorometric method for determination of sugars and related substances. Anal Chem. 1956; 28(3):350-58.

Ekau W, Auel H, Pörtner HO, Gilbert D. Impacts of hypoxia on the structure and process in pelagic communities (zooplankton, macro-invertebrates and fish). Biogeosciences. 2010; 7(5):1669-99.

Guderley H. Metabolic responses to low temperature in fish muscle. Biol Rev. 2004; 79(2):409-27.

He W, Cao ZD, Fu SJ. Effect of temperature on hypoxia tolerance and its underlying biochemical mechanism in two juvenile cyprinids exhibiting distinct hypoxia sensitivities Comp Biochem Physiol A. 2015; 187:232-41.

Hochachka PW, Lutz PL, Sick T, Rosenthal M, Van den Thillart G. Surviving hypoxia: mechanism of control and adaptation. Boca Raton: CRC Press; 1993.

Hochachka PW, Somero GN. Biochemical adaptation: mechanism and process in physiological evolution. New York: Oxford University Press; 2002.

Intergovernmental Panel on Climate Change (IPCC). Climate Change: Mitigation of Climate Change. Cambridge: Cambridge University Press; 2014.

Jackson DC. Surviving extreme lactic acidosis: the role of calcium lactate formation in the anoxic turtle. Respir Physiol Neurobiol. 2004; 144(2-3):173-78.

Jennings S, Wilson RW. Fishing impacts on the marine inorganic carbon cycle. J Appl Ecol. 2009; 46(5):976-82.

Kumar A, Gopesh A. Effect of hypoxia and energy conservation strategies in the air- breathing Indian catfish, Clarias batrachus. Natl Acad Sci Lett. 2015; 38(2):135-37.

Lutz PL, Nilsson GE. Contrasting strategies for anoxic brain survival. Glycolysis up or down. J Exp Biol. 1997; 200(Pt 2):411-19.

Martinez ML, Raynard EL, Rees BB, Chapman LJ. Oxygen limitation and tissue metabolic potential of the African fish Barbus neumayeri: roles of native habitat and acclimatization. BMC Ecol. 2011; 11:2. Available from: https://doi. org/10.1186/1472-6785-11-2

McBryan TL, Anttila K, Healy TM, Schulte PM. Responses to temperature and hypoxia as interacting stressors in fish: implications for adaptation to environmental change. Integr Comp Biol. 2013; 53(4):649-59.

McNeil DG, Closs GP. Behavioural responses of a southeast Australian floodplain fish community to gradual hypoxia. Freshw Biol. 2007; 52(3):412-20.

Omlin T, Weber JM. Hypoxia stimulates lactate disposal in rainbow trout. J Exp Biol. 2010; 213(Pt 22):3802-09.

Perazzo GX, Noleto RB, Vicari MR, Gava A, Cestari MM. Trends of karyotypical evolution in the pearl cichlid, Geophagus brasiliensis, from Southern Brazil. Zoology. 2013; 116(5):286-92.

Pörtner HO, Knust R. Climate change affects marine fishes through the oxygen limitation of thermal tolerance. Science. 2007; 315(5808):95-7. 
Pörtner HO, Peck MA. Climate change effects on fishes and fisheries: towards a cause-and-effect understanding. J Fish Biol. 2010; 77(8):1745-79.

Pörtner HO. Climate variability and the energetic pathways of evolution: the origin of endothermy in mammals and birds. Physiol Biochem Zool. 2004; 77(6):959-81.

Rantin FT, Petersen JA. Thermal tolerance of South American cichlid, Geophagus brasiliensis. Rev Hydrobiol Trop. 1985; 18(3): 221-26.

Roze T, Christen F, Amerand A, Claireaux G. Trade-off between thermal sensitivity, hypoxia tolerance and growth in fish. J Therm Biol. 2013; 38(2):98-106.

Saavedra LM, Quiñones RA, Gonzales-Saldía RR, Niklitschek EJ. Aerobic and anaerobic enzymatic activity of orange roughy (Hoplosthetus atlanticus) and alfonsino (Beryx splendens) from the Juan Fernandez seamounts area. Fish Physiol Biochem. 2016; 42(3):869-82.

Sørensen C, Munday PL, Nilsson GE. Aerobic vs. anaerobic scope: sibling species of fish indicate that temperature dependence of hypoxia tolerance can predict future survival. Glob Chang Biol. 2014; 20(3):724-29.
Stramma L, Johnson GC, Sprintall J, Mohrholz V. Expanding oxygen-minimum zones in the tropical oceans. Science. 2008(5876); 320:655-58.

Taylor JC, Rand PS, Jenkins J. Swimming behavior of juvenile anchovies (Anchoa spp.) in an episodically hypoxic estuary: implications for individual energetics and trophic dynamics. Mar Biol. 2007; 152(4):939-57.

Yang Y, Cao ZD, Fu SJ. Variations in temperature acclimation effects on glycosen storage, hypoxia tolerance and swimming performance with seasonal acclimatization in juvenile Chinese crucian carp. Comp Biochem Physiol A. 2015; 185:16-23.

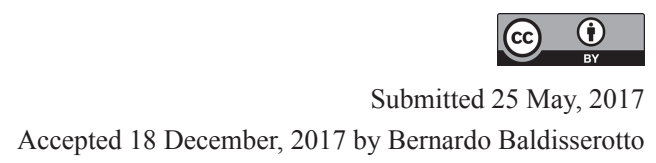

